\title{
PEMANFAATAN ICT UNTUK PENDIDIKAN PENCEGAHAN HIVIAIDS DI DAERAH PERBATASAN GREATER MEKONG SUBREGION
}

Oleh: Arief S Sadiman *

\section{Abstrak}

Dari sekitar 40 juta pengidap HIVIAIDS di dunia pada akhir tahun 2003, lebih dari 7 juta orang berada di kawasan Asia dan Pasifik. Hampir 2 juta di antaranya ada di negara-negara Greater Mekong Subregion (GMS): Kamboja, Laos, Myanmar, Thailand, Vietnam, dan propinsi YunnanCina. Angka ini meningkat dengan dibukanya daerah perbatasan untuk pariwisata dan perdagangan yang berdampak pada peningkatan arus penduduk melintas batas dan menyebarnya HIVIAIDS. Mayoritas penduduk perbatasan ini terutama wanitanya rentan akan infeksi dan tertular penyakit ini karena kurangnya akses ke layanan pendidikan dan kesehatan, kemiskinan, kurangnya informasi yang cocok secara budaya dalam bahasa daerah mereka, terisolirnya secara sosial dan kultural dari kelompok masyarakat lainnya, penggunaan obatobatan dan minuman keras, perdagangan manusia dan keterlibatan dalam perdagangan seks. Dalam kaitan ini, Organisasi Menteri-Menteri Pendidikan Asia Tenggara (SEAMEO), UNESCO, Departemen Pendidikan dan Departemen Kesehatan enam negara GMS telah merancang dan melaksanakan program pemanfaatan ICT untuk pendidikan pencegahan HIVIAIDS. Tulisan ini mengulas program SEAMEO di 36 SMP di kesembilan daerah perbatasan keenam negara GMS dan berbagi pengalaman serta pelajaran yang dapat dipetik dari program kerjasama regional tersebut.

Kata kunci: ICT, pendidikan pencegahan, HIVIAIDS, Greater Mekong Subregion (GMS)

\section{PENGANTAR}

Greater Mekong Subregion (GMS) terdiri dari Kamboja, Laos, Myanmar, Thailand, Vietnam, dan propinsi Yunnan yang semuanya dilalui sungai Mekong dan juga sama-sama menghadapi masalah HIVIAIDS. Laporan UNAIDS menyatakan bahwa di akhir 2003 jumlah pengidap HIVIAIDS dewasa (15-24 tahun) dan akan-anak di keenam negara tersebut adalah sbb: Kamboja - 170.000 orang; Laos -1.700 orang; Thailand -570.000 orang dan Vietnam 220,000 orang. Sementara itu Cina dilaporkan memiliki sekitar 840.000 kasus, separuh di antaranya tinggal di propinsi Yunnan. Kasus infeksi baru terus meningkat jumlahnya di antara para wanita yang bertanggungjawab untuk merawat mereka yang hidup dengan HIVIAIDS. Pada tahun 2001 misalnya, di Thailand saja
290,000 anak-anak (usia 0-14 tahun) terpaksa menjadi yatim gara-gara HIVIAIDS meningkat tajam dibandingkan dengan tahun 1999 yang hanya 75.000 orang anak.

Di Vietnam jumlah anak yatim sebanyak 22.000 orang, di Kamboja 55.000 orang meningkat empat kali lipat dibandingkan data 1999 yang hanya 13.000 orang anak. Meskipun pengidap HIVIAIDS dewasa di Laos masih rendah (kurang dari satu persen) lokasinya yang berdekatan dengan jalur lalu lintas obat terlarang, makin berbaurnya negara ini dengan kawasan GMS serta tingkat infeksi hubungan seks yang tinggi di beberapa tempat dapat mempermudah menyebarnya virus HIVIAIDS ini.

*) Dr Arief S Sadiman, adalah mantan Direktur SEAMEO Secretariat, Bangkok (2001 -2004). 
Di kalangan remaja, HIV juga dipandang sebagai ancaman terbesar. Beberapa faktor yang dapat meningkatkan kerentanan mereka akan HIV adalah kurangnya informasi tentang HIV, layanan pendidikan, dan kesehatan di samping keingintahuan serta coba-coba remaja, hubungan seksual paksa dan ketimpangan jender.

Kerjasama ekonomi melalui pendekatan "koridor ekonomi" telah membuka daerah perbatasan serta merangsang aktivitas ekonomi seperti misalnya pariwisata, zona khusus produksi dan perdagangan. Ini berakibat pada meningkatnya arus penduduk yang melintas perbatasan yang berimplikasi serius pada epidemiologi dan pencegahan HIVIAIDS. Hal ini terutama dipacu oleh kebutuhan para pekerja pria sepanjang perbatasan memenuhi kebutuhan biologisnya sehingga melahirkan lowongan kerja sebagai pekerja seks yang biasanya diisi oleh perempuan/ wanita penduduk setempat. Daerah perbatasan ini juga memberikan akses yang mudah sekali bagi penggunaan obat-obatan terlarang. Dalam kasus lain, orang-orang dari masrayarakat miskin sekitar perbatasan terkena infeksi HIV dan sekembali mereka pulang ke rumah masingmasing secara otomatis akan berfungsi sebagai jembatan penularan penyakitnya ke keluarga dan masyarakat sekitar mereka sepanjang perbatasan. Mayoritas penduduk kawasan GMS yang miskin sangat rentan akan HIVIAIDS karena kurangnya akses ke layanan pendidikan dan kesehatan, kemiskinan, kurangnya informasi, penggunaan obat-obatan, perdagangan manusia, kurangnya kesempatan kerja bagi para wanita, serta keterlibatan mereka dalam perdagangan seks.

Sampai saat ini belum ada obat untuk AIDS dan vaksin untuk itu sedang terus dikembangkan. Karenanya keberhasilan dalam mengurangi penyebarluasan virus HIV sangat tergantung pada perubahan perilaku dan penanganan faktorfaktor lingkungan dan sosial ekonomi yang meningkatkan kerentanan orang akan infeksi. Misalnya, menunda kegiatan seksual antar orang dewasa, dengan penekanan khusus pada anakanak perempuan, adalah faktor yang amat berperan pada pencegahan penularan HIV melalui kontak seksual. Faktor lainnya adalah menolak tekanan teman agar minum atau menyuntikkan obat-obatan. Semakin dini para remaja dijangkau oleh program-program pencegahan semakin besar harapan terkuranginya penyebab epidemik ini.

Pemanfaatan ICT dalam pendidikan dan kesehatan untuk pencegahan HIVIAIDS memiliki potensi yang kuat sekali namun sejauh ini belum banyak didayagunakan kerena keterbatasan infrastruktur (hardware dan software), tenaga yang terlatih dan sumber dana pendukung. Atas dasar itulah dengan dukungan dana dari Bank Pembangunan Asia (ADB) SEAMEO (Southeast Asia Ministry of Education Organization) bersama UNESCO mulai bulan Maret 2003 menyelenggarakan program pendayagunaan ICT untuk membantu mencegah penyebarluasan HIVI AIDS di daerah perbatasan Greater mekong Subregion (GMS).

\section{PERAN PENDIDIKAN PENCEGAHAN}

Program pendidikan pencegahan yang dilakukan di sekolah memegang peran penting bagi upaya pencegahan terutama untuk kalangan remaja. Upaya ini merupakan pendekatan yang ampuh bagi program pencegahan yang komprehensif. Lingkungan sekolah memiliki infrastruktur yang siap untuk penyampaian program pencegahan tersebut. Cara ini dapat menjangkau anak-anak dalam jumlah yang besar jauh sebelum mereka aktif secara seksual. Penggunaan pendekatan berdasar keterampilan dalam pendidikan pencegahan dapat meningkatkan keterampilan hidup yang memungkinkan para remaja untuk membuat keputusan yang benar yang melindungi mereka dari HIVIAIDS dan sekaligus juga akan membuka lebar kesempatan pendidikan dan ekonomi mereka.

Sekolah juga memiliki kemampuan yang lebih dibandingkan dengan lembaga-lembaga lain dalam melebarkan jangkauannya ke masyarakat. Ini merupakan pertimbangan penting karena proporsi para remaja yang makin rentan akan HIV sebenarnya adalah mereka yang ada di luar sekolah. Pendidikan pencegahan HIV bagi masyarakat yang dilakukan di sekolah akan memungkinkan terkoordinasikannya pesanpesan yang ditujukan pada populasi di lingkungan sekolah dan juga masyarakat.

Semua negara yang terlibat dalam program ini memiliki kebijakan Departemen Pendidikan serta perangkat hukum yang mendukung pelaksanaan pendidikan pencegahan HIVIAIDS di lingkungan sekolah. Kebijakan ini menekankan bahwa pelaksanaan pendidikan pencegahan HIVIAIDS dlakukan di semua jenjang pendidikan: dasar, menengah dan tinggi. Di beberapa negara malahan program ini dilaksanakan pula di lingkungan pendidikan guru.

Di Kamboja, misalnya, kebijakan dan strategi pengintegrasian HIVIAIDS untuk remaja di 
lingkungan sekolah dan luar sekolah dimasukkan dalam Renstra Pendidikan Departemen Pendidikan, Pemuda dan Olah Raga mereka. Keputusan Departemen Pendidikan dan Pelatihan Vietnam menegaskan pentingnya pendidikan pencegahan HIVIAIDS. Peraturan di propinsi Yunnan mensyaratkan semua sekolah melaksanakan pendidikan pencegahan HIVI AIDS. Di Laos, sementara itu, sebuah Tim Pendidikan AIDS di dalam Departemen Pendidikan telah dibentuk pada tahun 1996 dan bertanggungjawab atas pelaksanakan pendidikan pencegahan menyusul dibentuknya komisi nasional untuk pengontrolan AIDS (National Committee for the Control of AIDS/ NCCA). Kebijakan Departemen Pendidikan di Thailand menekankan hak setiap anak memahami dan menyadari bahaya HIVIAIDS.

Pelaksanaan pendidikan pencegahan di lingkungan sekolah dilaksanakan melalui kegiatan-kegiatan kurikuler dan ko-kurikuler. Kurikulum negara-negara tersebut diperbaiki untuk mengintegrasikan konsep HIVIAIDS di sejumlah mata pelajaran dengan menggunakan pendekatan keterampilan hidup. Mata pelajaranmata pelajaran tersebut mencakup pendidikan kesehatan, biologi, civic dan pendidikan moral, serta bahasa. Tim pendidikan AIDS dibentuk dan anggotanya berasal dari berbagai direktorat/ unit kerja di lingkungan Departemen Pendidikan dan Departemen Kesehatan. Namun demikian, cakupan dan lingkup pelaksanaannya bervariasi dari satu negara ke negara lain. Ada beberapa isu dan keprihatinan yang berpengaruh pada efektifitas dan efisiensi pelaksanaannya. Dua dari keprihatinan tersebut adalah ketepatan bahan belajar mengajar serta metode pengajarannya.

\section{PEMANFAATAN ICT}

Pemanfaatan ICT dalam pendidikan pencegahan HIVIAIDS dapat meningkatkan proses belajar dan mengajar secara sungguh-sungguh. Intervensi berbasis ICT yang tepat sasaran, kreatif, interaktif, integratif dan kontekstual dapat meningkatkan efektivitas dan efisiensi proses belajar-mengajar. Bahan-bahan yang dikembangkan bersama para siswa mampu menjawab permasalahan khusus yang dihadapi warga sekolah. Selanjutnya bahan-bahan ajar pendidikan berbasis ICT dapat disimpan di sekolah agar siap pakai sesuai dengan kebutuhan dan memungkinkan keluwesan dalam pemakaian serta belajar sesuai kecepatan diri masing-masing. Perlu ditekankan bahwa tujuan akhir program ini bukanlah hanya pada pengenalan ICT. Intervensi ICT yang dilakukan terintegrasi dalam proses pendidikan yang lebih luas. ICT telah merangsang belajar kawasan kognitif tingkat tinggi seperti misalnya pemecahan masalah melalui tugas-tugas kreatif yang melibatkan semua siswa baik di dalam kegiatan kelas maupun luar sekolah.

Sebelum program ini dilaksanakan pemanfaatan ICT untuk pendidikan pencegahan HIVIAIDS di semua negara GMS belum didayagunakan secara maksimal. Diyakini bahwa ICT akan mampu menjawab dua tantangan pokok dalam pendidikan pencegahan: meningkatkan lingkungan dan metode belajar-mengajar serta memungkinkan dikembangkannya bahan-bahan ajar yang sesuai pada saat pelaksanaan program dengan dana yang terbatas.

\section{PROGRAM SEAMEO-ADB}

Sebagai bagian dari bantuan teknis regional untuk meningkatkan pengembangan Sumbe Daya Manusia dan pengurangan kemiskinan di Greater Mekong Sub-region (GMS), Bank Pembangunan Asia (ADB), memberikan bantuan teknis senilai $\$ 1,000,000$ untuk menunjang proyek regional Pemanfaatan ICT untuk Pendidikan Pencegahan HIVIAIDS di daerah perbatasan GMS untuk jangka waktu 18 bulan terhitung mulai Maret 2003.

SEAMEO (The Southeast Asian Ministers of Education Organization) dan UNESCO (The United Nations Educational, Scientific and Cultural Organization) dipercaya sebagai lembaga pelaksana program ini dengan tanggungjawab bagian program masing-masing dengan dana sekitar $\$ 500,000$. Kesepakatan kerjasama antara SEAMEO dan ADB ditandatangani pada 7 Maret 2003 di Manila. Komponen SEAMEO dilaksanakan oleh Sekretariat SEAMEO beserta 3 regional center nya yang relevan yaitu SEAMEO TROPMED (Regional center for Tropical Medicine, Thailand), SEAMEO INNOTECH (Regional center for Education Innovation and Technology,Filipina) dan SEAMEO SEAMOLEC (Regional Center for Open Learning, Indonesia) bekerjasama dengan nagara GMS (Kamboja, Laos, RRC/ Propinsi Yunnan, Thailand, Myanmar dan Vietnam). Fokus program ini adalah perluasan pemanfaatan ICT dan teknologi multimedia lainnya oleh para guru untuk pendidikan pencegahan HIVIAIDS di sekolah-sekolah daerah perbatasan GMS yang terpilih.

Jumlah dana keseluruhannya adalah US \$1,85 juta. Rinciannya ADB US \$ 1 juta.- SEAMEO US 
\$ 431.000 dan UNESCO US \$ 317.000. Sementara itu kelima negara GMS menyumbang dana sebesar US \$100.000,- serta sumbangan lain yang berbentuk narasumber dan fasilitator.

\section{TUJUAN}

Bantuan teknis ADB ini memiliki dua tujuan pokok yaitu ; (i) mengurangi terjadinya infeksi HIVISAIDS di antara kelompok usia rentan, kelompok miskin serta penduduk pinggiran; dan (ii) memasyarakatkan pemanfaatan ICT serta teknologi multimedia lainnya dalam pendidikan pencegahan HIVIAIDS.

Secara khusus program kerjasama ini dimaksudkan untuk: (i) mengembangkan bahanbahan ajar pendidikan pencegahan HIVIAIDS dalam bahasa daerah setempat; (ii) meningkatkan kemampuan para guru, penyuluh kesehatan, pembuat program multimedia, dan pemangku peran dalam pendidikan pencegahan HIVIAIDS lainnya; (iii) memperluas pemanfaatan ICT dalam pendidikan pencegahan HIVIAIDS; dan (iv) menyampaikan program pencegahan yang berbasis ICT kepada masyarakat yang terisolir, terpinggirkan dan rentan.

Sebagaimana dikatakan tadi ada dua lembaga internasional pelaksana program ini yaitu SEAMEO dan UNESCO. Komponen SEAMEO berfokus pada para guru dan remaja di sekolah dan secara tidak langsung juga menggarap masyarakat tempat sekolah yang dipilih berada. Komponen ini dilaksanakan di 9 daerah perbatasan antara kelima negara yang berperanserta: Kamboja, Laos, Thailand, Vietnam dan propinsi Yunnan, RRC. Ada 36 SMP yang menjadi garapan program ini, masing-masing dua sekolah di setiap wilayah perbatasan.

\section{KOMPONEN PROGRAM DAN SASARAN}

Ada empat komponen program ini yaitu: (i) Pengembangan Bahan Ajar yang dilakukan oleh unit terkait di tingkat propinsi dan sekolah untuk menjamin kesesuaian dengan kondisi dan kebutuhan setempat. Bahan-bahan ajar yang dikembangkan ini menjawab tiga permasalahan yang terkait satu sama lain yaitu perilaku rawan HIVIAIDS, perdagangan perempuan dan anakanak serta penyalahgunaan obat-obatan di kalangan minoritas yang tinggal di perbatasan. (ii) Pengembangan kemampuan kelompokkelompok remaja dan wanita di masyarakat yang memberikan dukungan lanjutan setelah sasaran menerima program pencegahan di sekolah. (iii)
Penyampaian program yang dilakukan melalui kurikulum dan kegiatan pembelajaran di sekolah dengan guru sebagai agen perubahan dan penggerak masyarakat. (iv) Dukungan database dan informasi yang meliputi a.l. pengumpulan , pengolahan, penyebarluasan dan berbagi bahanbahan informasi tentang HIVIAIDS untuk selanjutnya dipelajari, dikemas ulang sesuai dengan target sasaran setempat.

Target sasaran program ini adalah 8,000 remaja usia sekolah (usia 13-24 tahun) di daerah perbatasan GMS , selain remaja di luar sekolah dan kelompok resiko tinggi seperti supir truk dan pekerja seks komersial.

Dari sekitar 240 juta penduduk GMS ada 21 juta orang yang berasal dari kelompok etnis minoritas. Kurangnya akses terhadap layanan pendidikan dan kesehatan, meningkatnya penyalahgunaan obat-obatan serta perdagangan seks telah menempatkan wanita pada kelompok beresiko tinggi kena HIVIAIDS.

\section{LOKASI KEGIATAN}

Ada 11 lokasi perbatasan yang diusulkan negara peserta yaitu :

\section{Kamboja:}

1. Poipet dengan Aranyaprathet (berbatasan dengan Thailand)

2. Koh Kong dengan Trat (berbatasan dengan Thailand)

Laos:

1. Borikhamsay dengan Ha Tinh (berbatsan dengan Vietnam)

2. Vientiane dengan Nongkhai (berbatasan dengan Thailand)

\section{Yunnan:}

1. Ma Li Po dengan Ha Giang (berbatasan dengan Vietnam)

2. Mung La dengan Luang Nam Tha (berbatasan dengan Laos)

3. Ying Jiang dengan Muse (berbatasan dengan Myanmar)

\section{Vietnam:}

1. Muongte, Lai Chau dengan Phongsaly (berbatasan dengan Laos)

2. Moungte dengan Honghe Prefecture (berbatasan dengan Yunnan)

3. Ha Tinh dengan Borikhamsay (berbatasan dengan Laos)

4. Longan dengan Svay Rieng (berbatasan dengan Cambodia) 


\section{Thailand:}

1. Chiang Rai dengan Bokeo (berbatasan dengan Laos)

Pertimbangan pemilihan ke sembilan daerah tersebut adalah potensi penyebaran infeksi, mendesaknya kebutuhan akan pendidikan pencegahan, situasi sekitar yang menunjang seperti suasana aman, tidak ada konflik perbatasan, komitmen dan dukungan para pejabat setempat, serta kegiatan yang terkait dengan HIVIAIDS yang sedang berlangsung di sana. Dari segi kondisi sosial ekonomi, penduduknya tergolong masyarakat miskin. Kecuali itu di daerah tersebut populasi pelintas batas juga relatif tinggi karena alasan ekonomi sementara adanya kegiatan ekonomi, seperti misalnya kasino atau panti hiburan lainnya, justru berdampak pada berkembang suburnya perdagangan seks.

Tingginya kerentanan daerah perbatasan tersebut akan HIV nampak dari jumlah kasus HIV. Di Kamboja, misalnya tingkat prevalensi HIV di antara pekerja seks komersial di tiga propinsi yang terlibat secara berturut-turut 37\%, 51\% dan $36 \%$. Sementara itu di antara wanita yang hamil secara berturut-turut $4.4 \%, 3.3 \%$ and $1.7 \%$. In Laos, dilaporkan ada 38 kasus di dua propinsi yang dibina atau sekitar $3.13 \%$ dari seluruh kasus di negeri itu. Di tiga propinsi binaan di Thailand, didapati 709 kasus, sementara di Vietnam, di lima propinsi yang terlibat ada 211 kasus. Malahan di 6 SMP yang dibina di Thailand ada 36 orang siswa yang telah terinfeksi HIVI AIDS. Di propinsi Yunnan, tidak tersedia data yang pasti, namun laporan tak resmi membenarkan adanya cukup banyak kasus sepanjang perbatasan. Beredar cerita adanya kepercayaan setempat apabila sudah terinfeksi HIVIAIDS hanya bisa sembuh apabila berhubungan dengan perawan.

Pemilihan daerah perbatasan juga didasarkan pertimbangan menjangkau penduduk minoritas. Di Laos misalnya, ada sekitar 36 kelompok etnis di 4 propinsi binaan program dari keseluruhan 49 kelompok etnis di seluruh Laos. Di Yunnan, proporsi yang cukup signifikan dari penduduk di empat sekolah binaan adalah kelompok minoritas. Peta berikut menunjukkan daerah perbatasan yang terlibat dalam program ini.

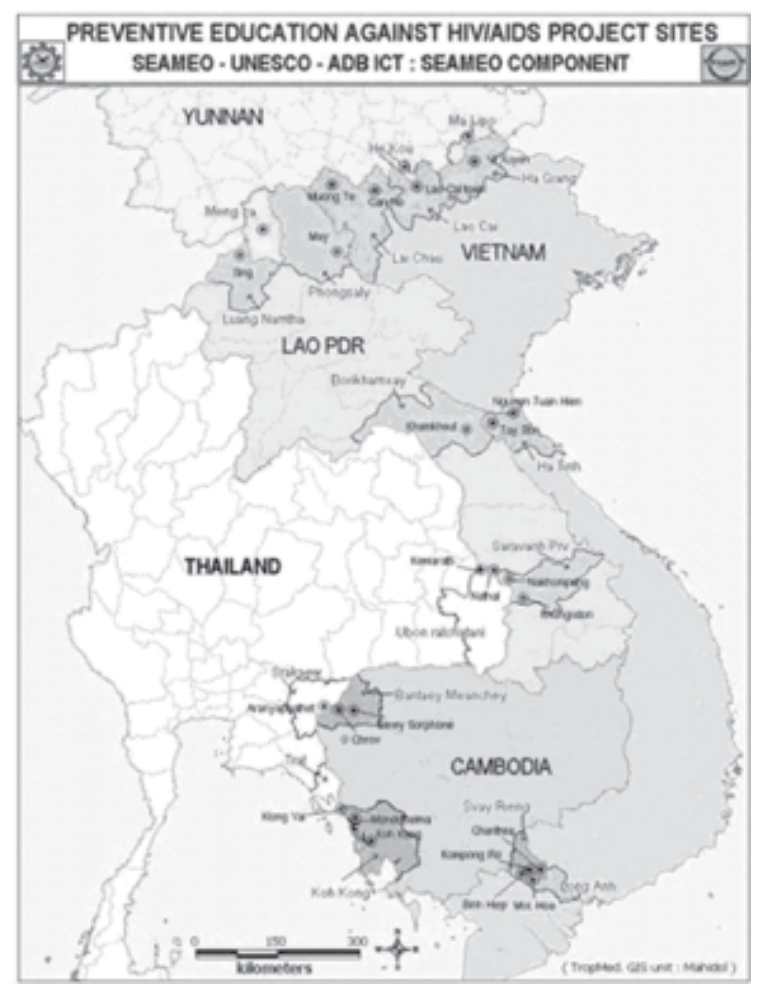

Atas dasar kriteria tersebut di atas, dengan tidak ikutnya Myanmar dalam program ini, secara kolektif akhirnya dipilihlah 9 daerah perbatasan sbb.:

1. Koh Kong, Cambodia berbatasan dengan Trad, Thailand

2. Bantaey Meanchay, Cambodia berbatasan dengan Sakeo, Thailand

3. Svay Rieng, Cambodia berbatasan dengan Long Anh, Vietnam

4. Phongsaly, Laos berbatasan dengan Lai Chau, Vietnam

5. Luang Namtha, Laos berbatasan dengan Muong La, Yunnan

6. Borikhamsay, Laos berbatasan dengan $\mathrm{Ha}$ Tinh, Vietnam

7. Saravanh, Laos berbatasan dengan Ubon Ratchathani, Thailand

8. Ha Giang, Vietnam berbatasan dengan Malipo County, Yunnan

9. Lao Cai, Vietnam berbatasan dengan $\mathrm{He} \mathrm{Kou}$ County, Yunnan

\section{TAHAPAN KEGIATAN}

Program pemanfaatan ICT untuk pendidikan pencegahan HIVIAIDS ini dilakukan melalui tahapan berikut: (i) analisis situasi sekolah dan lapangan; (ii) pelatihan pelatih nasional di SEAMEO INNOTECH untuk meningkatkan keterampilan mereka dalam merancang pembelajaran, pemanfaatan peralatan ICT (word processing, penyajian, spread sheet, video) dan 
produksi prototipa bahan ajar berbasis ICT; (iii) pemberian peralatan ICT dasar ke lima tim nasional dan 36 sekolah binaan; (iv) pelatihan penggunaan ICT bagi guru sekolah yang melaksanakan pendidikan pencegahan dan pengembangan bahan ajar yang dibuat siswa sendiri di tingkat sekolah; (v) pengembangan bahan ajar; (vi) penyampaian program pendidikan pencegahan dengan memanfaatkan ICT di lingkungan sekolah; (vii) pendidikan pencegahan bagi masyarakat; (viii) pengembangan data base; dan (ix) monitoring/ evaluasi.

\section{ANALISIS SITUASI SEKOLAH DAN LAPANGAN}

Untuk mendapatkan gambaran yang jelas tentang situasi lapangan dan mendapatkan persetujuan akan tujuan, lingkup dan pelaksanaan program dari SEAMEO, UNESCO serta negara-negara GMS yang berperan serta, sebuah lokakarya temu fakta dilaksanakan pada 29-31 Juli 2002 di Bangkok. Pesertanya adalah wakil dari ke enam negara tersebut, kecuali Myanmar, satu orang masing-masing dari kesehatan (HIVIAIDS), pendidikan dan sektor ICT, serta staff SEAMEO, ADB dan UNESCO.

Masing2 negara memberikan sajian situasi mutakhir HIVIAIDS dengan fokus ke daerah perbatasan serta kelompok sasaran (anak sekolah, etnis minoritas, masyarakat yang terpencil dan susah dijangkau); pendidikan pencegahan yang meliputi program secara umum, strategi pokoknya, cakupan, bahan yang digunakan dan tantangan yang dihadapi; kondisi infrastruktur ICT yang ada terutama di daerah perbatasan, kebijakan dan rencana pengembangan ICT serta pemanfaatan ICT yang telah ada.

Setelah itu dilanjutkan dengan sesi tanya jawab dan tanggapan peserta akan sajian tersebut. Makalah yang disiapkan masing-masing negara telah memberikan informasi yang cukup lengkap untuk memahami situasi yang kita hadapi.

Setelah workshop dilanjutkan dengan kunjungan lapangan ke perbatasan Thailand dan Kamboja pada tanggal 2-3 Agustus 2002 ke sekolah menengah pertama di Kabupaten Aranyaprathet , propinsi Sa Keo perbatasan Thailand dan Kamboja lalu menyeberang ke Poi Pet di wilayah Kamboja melihat sekolah Banteay Mean Chey. Dari dialog dengan para siswa diperoleh jawaban sebagian besar mereka, terutama murid perempuan setelah tamat akan bekerja di Casino yang bertebaran megah di wilayah Kamboja.
Alasannya mereka melihat teman-temannya yang bekerja di tempat perjudian tersebut berubah penampilannya, bajunya bagus dan berduit, Nampak mereka tidak peduli walaupun harus menjual dirinya. Perjudian, minuman keras, penggunaan obat terlarang dan pelacuran memang sangat erat berkaitan satu sama lain.

\section{PENGEMBANGAN BAHAN AJAR}

Lokakarya pengembangan dan pemanfaatan bahan ajar berbasis ICT dilaksanakan di SEAMEO INNOTECH,Manila, Filipina, selama 2 minggu di bulan Juni 2003. Pesertanya adalah calon pelatih dari negara GMS, masing-masing 2 orang. Ini merupakan awal dari rangkaian lokakarya yang mereka lakukan di negara masing-masing untuk membuat ba-han ajar pencegahan HIVIAIDS bagi siswa SMP di daerah perbatasan GMS yang rentan tertular.

Fokus lokakarya adalah mengembangkan bahan ajar berbasis ICT untuk pencegahan HIVIAIDS dan merumuskan strategi pemanfaatannya. Bahan dan strategi ini dikem-bangkan lebih lanjut di pelatihan tingkat nasional dan sekolah masingmasing dengan bantuan teknis staf SEAMEO INNOTECH, termasuk penerjemahannya ke bahasa setem-pat. Koleksi bahan ajar tersebut selanjutnya di share dengan sekolah lain . Lokakarya bagi pelatih inti dari masing-masing negara ini telah memberikan bekal pengembangan dan pemanfaatan bahan ajar pencegahan HIVIAIDS. Mereka selanjutnya melatih para guru SMP di daerah binaan proyek. Jenis bahan ajar berbasis ICT tergantung pada ketersediaan ICT di masing-masing daerah yang dapat diakses oleh guru maupun siswa.

Ada empat teknologi yang dilatihkan: (i) word processing untuk menghasilkan bahan cetak interaktif; (ii) electronic spreadsheet untuk membuat bahan ujian; (iii) aplikasi pre-sentasi yang bermanfaat bagi sajian guru dan bahan ajar mandiri siswa ; dan (iv) video berisi pesanpesan penguatan. Untuk menilai kelayakan bahan yang mereka hasillkan di-lakukan simulasi pelatihan guru.

Topik latihan dalam lokakarya tersebut meliputi kajian sumber-sumber belajar yang telah ada yang mereka bawa atau yang tersedia di INNOTECH, penyusunan rancangan pembelajaran, pengembangan bahan ajar cetak, video dan berbasis komputer; perencanaan serta pelaksanaan produksi bahan ajar tersebut. Peserta juga dibawa ke Yayasan AIDS Remedios, salah satu LSM paling aktif di Filipina yang 
bergerak dalam sektor kesehatan reproduksi dan seksual untuk melihat contoh-contoh bahan informasi, komunikaksi dan edukasi HIVIAIDS.

Selama lokakarya peserta mengembangkan prototipa bahan ajar berbasis ICT yang dapat digunakan di lingkungan sekolah untuk menunjang pendidikan pencegahan HIVIAIDS. Bahan2 itu disempurnakan dan dikembangkan lebih lanjut di lokakarya tingkat nasional dan sekolah di masing-masing negara.

Kegiatan selama dua minggu tersebut menghasilkan petunjuk pelatihan bagi guru tentang bagaimana memproduksi dan menggunakan bahan ajar pencegahan HIVIAIDS berbasis ICT; kumpulan prototipa bahan ajar pencegahan HIVIAIDS untuk digunakan di SMP; bahan-bahan pengayaan yang relevan serta rencana tindak lanjut.

\section{PELATIHAN}

Pelatihan di tingkat sekolah dan nasional selanjutnya dilaksanakan, termasuk cara-cara penularan HIVIAIDS dan pencegahan infeksi diberikan di 36 sekolah yang berpartisi-pasi. Metode pembelajaran yang efektif diperkenalkan dan cara-cara inovatif dalam pengembangan dan pemanfaatan bahan ajar berbasis ICT diajarkan. Mereka juga diajari menggunakan komputer untuk menunjang pelatihan guru dan staf sekolah.

Para siswa juga diarahkan untuk membuat bahan-bahan ajar sebagai bagian dari proses belajar dan pada saat yang sama dapat digunakan untuk mengajari teman sebaya. Berbagai macam bahan ajar telah dibuat dan dimanfaatkan seperti misalnya poster, stiker, brosur, slogan, lagu, video klip, permainan simulasi, permainan peran yang semuanya berisi pesan pencegahan HIVIAIDS. Pemanfaatannya di kelas diintegrasikan ke dalam mata pelajaran yang relevan.

Di Laos, pelatihan dilaksanakan dua tahap. Kepala Sekolah dan pengawas dari 8 SMP yang ikut dalam program ini mengikuti bagian pertama pelatihan yang memberikan orientasi tentang program serta informasi dasar yang diperlukan untuk pendidikan pencegahan HIVIAIDS. Bagian kedua mengajarkan pemanfaatan peralatan ICT pada guru-guru yang akan menggunakan bahan ajar tadi. Sementara itu di Thailand dan Vietnam pelatihan hanya diberikan pada para guru dari sekolah-sekolah yang terlibat.

Kecuali pelatihan infrastruktur ICT juga ditingkatkan. Semua sekolah dilengkapi dengan perangkat ICT termasuk komputer, mesin faksimili, scanners, OHP, kamera video, kamera digital, pesawat televise, DVD player serta amplifier. Jenis peralatan ICT yang diadakan tergantung pada kesiapan dan kebutuhan sekolah yang bersangkutan. Pengadaan peralatan tersebut dilakukan oleh masing-masing negara peserta. Kecuali untuk menunjang program pendidikan pencegahan HIVIAIDS peralatan ini ternyata banyak dimanfaatkan pula untuk menunjang program lain yang relevan.

\section{HASIL DAN PELAJARAN}

Dalam waktu sekitar dua tahun program ini telah memberikan hasil sbb:

- Satu kurikulum pelatihan tingkat regional dan lima kurikulum pelatihan tingkat nasional serta manual dalam bahasa setempat tentang pemanfaatan ICT dalam pendidikan pencegahan;

- Telah ditingkatkannya kemampuan ICT 10 orang pelatih tingkat nasional;

- Telah meningkatnya kemampuan 614 orang guru di 9 daerah perbatasan dalam menggunakan ICT, jauh lebih besar dari target semula yang hanya 200. Lebih dari separuhnya $(57,82 \%)$ adalah guru wanita.

- Sebanyak 650 bahan ajar telah dibuat dengan menggunakan komputer, seperti selebaran (flyer), brosur, newsletter, poster dan bahanajar pop-up; 207 buah bahan sajian powerpoint, 15 buah program video berbahasa local; 79 perma-inan interaktif berbasis ICT; 8 buah VCD berisi lagu-lagu rakyat; dan 6 buah program radio untuk masyarakat setempat;

- Sebanyak 26,679 orang siswa SMP telah terlayani dengan pendidikan pence-gahan dengan menggunakan ICT, hampir separuhnya $(46,79 \%)$ adalah siwa perempuan;

- Sekitar 100.000 orang penduduk daerah perbatasan telah terjangkau oleh kegiatan pendidikan pencegahan ini;

- Kemampuan ICT 36 sekolah yang dibina dan juga tim nasional telah diperkuat; serta

- Data base berbasis Web telah dikembangkan.

Kecuali itu secara tidak langsung kita dapati pula hasil-hasil lainnya sbb:

- $\quad$ terbentuknya budaya ICT di lingkungan 36 sekolah sehingga sedikit banyak mengurangi kesenjangan ICT;

- adanya kepuasan moral para guru yang terlibat dalam menyampaikan program;

- meningkatnya minat, perhatian dan peran 
serta aktif para siswa ;

- tingginya komitmen kepala sekolah dan pemuka serta anggota masyarakat dalam program seperti terwujud dalam bentuk pemberian dukungan dana untuk membangun infrastruktur untuk menampung peralatan ICT; penyambungan aliran listrik ke beberapa sekolah yang semula terisolir di Laos dan peran serta mereka dalam berbagai kegiatan bersama sekolah-masyarakat;

- telah dirintisnya kerjasama dan kegiatan bilateral lintas perbatasan negara-negara yang terlibat;

- terbukanya akses ke penduduk miskin dan terpinggirkan di daerah perbatasan; dan juga akses ke anak perempuan dan wanita di sekolah dan masya-rakat serta terpenuhinya kebutuhan mereka untuk mengurangi kerentanan mereka akan HIVIAIDS.

\section{PELAJARAN APA YANG DAPAT DIPETIK DARI PROGRAM INI?}

- Program ini telah berhasil mempererat kerjasama antar sektor pendidikan dan kesehatan mulai dari tingkat kabupaten, propinsi hingga nasional. Para peja-bat di tingkat lapangan juga jadi lebih terlibat dalam kegiatan sekolah. Koordinasi yang semula sulit diwujudkan dengan model yang diberikan pro-gram ini mulai kelihatan tumbuh di sebagian besar lokasi.

- Dukungan dan kerjasama berbagai pihak terkait sangat menentukan keber-hasilan program ini. Peran serta dan komitmen orangtua dan pemuka masya-rakat mulai dari saat persiapan program hingga pelaksanaan sangat memper-mudah pencapaian tujuan program ini. Di beberapa sekolah masyarakat ber-sedia memperbaiki bahkan membangun ruangan tambahan untuk mengako-modasi kegiatan proyek.

- Hubungan sekolah dan masyarakat yang erat memungkinkan apa yang diha-silkan dan digunakan di sekolah juga dimanfaatkan untuk pembelajaran te-man sebaya di masyarakat.

- Program ini juga telah memberi model pengintegrasian pendidikan pence-gahan HIVIAIDS berbasis ICT ke dalam kurikulum sekolah tanpa terlalu banyak menambah jam pelajaran.

- Keterlibatan siswa dalam membuat bahan ajar meningkatkan motivasi dan mempermudah mereka menyerap pesan dan menyebarkannya pada teman sebayanya.

- Pendidikan pencegahan HIVIAIDS sangat diperlukan oleh masyarakat miskin dan terpinggirlkan terutama yang tinggal di daerah perbatasan.

- Kemiskinan tidak mungkin akan dihapuskan sama sekali selama orang tidak tahu bagaimana hidup dengan cara yang sehat dan melindungi diri mereka sendiri dari berbagai penyakit. Dengan memusatkan kegiatan di daerah per-batasan program ini telah memperkenalkan cara belajar yang baru yang amat mereka perlukan.

- Keberhasilan program ini karena disesuaikan dengan situasi dan kondisi se-tempat, dilaksanakan oleh orang-orang setempat yang tahu persis kebutuhan masyarakat mereka, menggunakan bahasa dan disesuaikan dengan nilai-nilai serta kepercayaan setempat. Perasaan ikut memiliki program terbentuk dengan dilibatkannya mereka sejak perencanaan program, pemilihan lokasi, pengembangan bahan-vbahan, pengadaan peralatan ICT hingga pelaksanaan dan pemantauan hasilnya. Oleh karena mereka mampu memahami permasalahan HIVIAIDS yang ada di lingkungan mereka serta mengembangkan cara-cara pemecahannya suatu tradisi belajar telah pula tertanamkan.

- Di barisan terdepan program ini adalah sekolah yang dengan intervensi ICT telah diperkuat menjadi Pusat Sumber Belajar Masyarakat. Pemanfaatan ICT yang tidak diisolir di ruangan komputer tetapi melebur dalam kegiatan belajar mengajar sehari-hari di kelas dan juga di kegiatan masyarakat telah menjawab masalah-masalah kesehatan yang menjadi keprihatinan bersama.

- Peralatan ICT yang diberikan dimanfaatkan dengan maksimal karena para pelatih, guru dan siswa dibekali dengan pengetahuan dan kemampuan dalam menggunakannya dengan benar. Transfer teknologi berjalan dengan baik bah-kan di daerah yang semula tidak pernah tersentuh listrik dan teknologi seder-hana karena disadari benar bahwa ICT hanyalah alat sementara kunci keberhasilannya ada di manusianya.

- Pelajaran yang paling menggembirakan dari program ini adalah telah terben-tuknya budaya ICT di kalangan guru, siswa, tokoh masyarakt bahkan orang tua yang telah memberi mereka ke keterampilan hidup dalam mencari informasi, memperoleh pengetahuan, menggunakan pengetahuan dan informasi tersebut dalam interaksi dan komunikasi di antara mereka dengan secara cer-das menggunakan ICT. Ini merupakan bagian dari upaya global membangun masyarakat yang bebas dari HIV. 


\section{SUMBER BACAAN}

Asian Development Bank, Report on Inception Workshop: ICT and HIVIAIDS Preventive Education in the Cross Border Areas of the Greater Mekong Subregion, Bangkok, 2003 , ICT and HIVIAIDS Preventive Education in the Cross-Border Areas (TA. No 6083), Manila, 2003

SEAMEO, Center Director Meeting Report, Bangkok, 2004

UNESCO, HIVIAIDS in the GMS: Bulletin for Preventive Education in the Greater Mekong Subregion, Issue 1, Bangkok, 2004 